urea in the stomach to produce ammonia. We therefore postulate that ammonia increases the $\mathrm{pH}$ in the mucus layer that overlies the gastric antrum, resulting in impairment of the normal inhibition of gastrin release by intraluminal acid.

This is the first report of a fall in postprandial plasma gastrin responses after eradication of $H$ pylori in patients with duodenal ulcers. This could explain the reduced likelihood of relapse of ulcers in patients treated with agents that suppress or eradicate $H$ pylori. The fall in postprandial plasma gastrin concentrations, which does not occur after treatment with $\mathrm{H}_{2}$ antagonists $^{5}$ and is therefore not simply a result of the ulcer healing, would be expected to result in a diminished postprandial secretory drive on the gastric parietal cells. Another probable long term result of the lower gastrin concentrations is a reduction in the number of parietal cells owing to a reduction in the trophic effect of gastrin on these cells. Peak acid output, which reflects the parietal cell mass, did not fall significantly in our patients after one month of treatment to eradicate $H$ pylori despite the lower gastrin concentrations. Thus a longer period of treatment may be needed before the number of parietal cells falls.

We thank Sister M L Francis Reme and her endoscopy staff for their hard work and $\mathrm{Mr}$ John Spencer for allowing us to study his patients. SL was supported by the British Digestive Foundation, KB by the Wellcome Trust, and RP by the Medical Research Council.

1 Marshall BJ, Goodwin CS, Warren JR, et al. Prospective double-blind trial of duodenal ulcer relapse after eradication of Campylobacter pylori. Lance 1988;ii:1467-9.

2 Levi S, Beardshall K, Haddad G, Playford R, Ghosh P, Calam J. Campylobacter pylori and duodenal ulcers: the gastrin link. Lancet 1989;i:1167-8.

3 O'Riordan T, 'Tobin A, Beattie S, Sweeney E, Keane C, O'Morain C. Adjuvant metronidazole improves eradication of Campylobacter pylori in duodenal metronidazole improves eradication of Campylobacter pylor1 in

4 Walsh JH, Richardson CT, Fordtran JS. pH Dependence of acid secretion and alsh JH, Richardson CT, Fordtran JS. pH Dependence of acid secretion
gastrin release in normal and ulcer subjects. $\mathcal{f}$ Clin Invest $1975 ; 55: 462-8$. gastrin release in normal and ulcer subjects. F Clin Invest 1975;55:462-8.
5 Forrest JAH, Fettes MR, McLaughlin GP, Heading RC. Effect of long-term cimetidine on gastric secretion, serum gastrin, and gastric emptying. Gut 1979;20:404-7.

(Accepted 20 September 1989)

\section{Erythrocyte zinc concentrations in subacute (de Quervain's) thyroiditis}

\section{C Chow, C C Shek, Y T Mak, C S Cockram, R Swaminathan}

Departments of Medicine and Chemical Pathology, Chinese University of Hong Kong, Shatin, NT, Hong Kong

C C Chow, MRCP, medical officer, department of medicine $\mathrm{CC}$ Shek, MB, medical officer, department of chemical pathology

Y T Mak, MPHIL, scientific officer, department of chemical pathology

C S Cockram, FRCP, senior

lecturer in medicine

R Swaminathan, MRCPATH,

professor of chemical pathology

Correspondence to:

Dr Shek.

BrMed F 1989;299:1505-6
Patients with subacute thyroiditis classically present with fever, neck pain, and a tender goitre. Functional changes in thyroid state include both hyperthyroidism and hypothyroidism. Constitutional symptoms may, however, be absent and patients may present with features of hyperthyroidism alone, thus making differentiation from other causes of hyperthyroidism difficult. Nevertheless, differentiation is important as the implications for treatment are different. In such cases measurement of the uptake of radioiodine by the thyroid gland is useful, but it may not be measured unless thyroiditis is suspected. Thus the disorder may be misdiagnosed and patients given inappropriate treatment.

As patients with subacute thyroiditis are hyperthyroid for a short time a marker that reflects the duration of their hyperthyroidism might be useful in differentiating their condition from established hyperthyroidism - for example, that due to Graves' disease. Erythrocyte zinc concentrations are decreased in patients with established hyperthyroidism. 'Because, however, the circulating life span' of erythrocytes is long, the erythrocyte zinc concentration reflects the integrated functional state of the thyroid over a period of months. Thus the erythrocyte zinc concentration may be used to differentiate between transient hyperthyroidism and established hyperthyroidism lasting more than two to three months. We previously reported that the erythrocyte zinc concentration differentiated between transient hyperthyroxinaemia associated with hyperemesis gravidarum and preexisting thyrotoxicosis, ${ }^{2}$ and we report the results in patients with transient hyperthyroidism associated with subacute thyroiditis.

\section{Patients, methods, and results}

We studied five patients (four women and one man ranging in age from 35 to 42 ) with clinically incontrovertible subacute thyroiditis. Hyperthyroidism was suspected clinically in four of them and was confirmed in all five by measuring the concentrations of thyroid hormones. All five patients presented with fever, anterior neck pain, a tender goitre, and a raised erythrocyte sedimentation rate (mean $111 \mathrm{~mm}$ in the first hour, range 58-150); the uptake of radioactive iodine by the thyroid gland was subnormal in all five and none had thyroid antibodies.

Erythrocyte zinc concentrations were measured by atomic absorption spectrophotometry. ${ }^{\prime}$ The coefficient of variation between days was $5 \%$.

Erythrocyte zinc concentrations in the five patients were compared with those in 30 patients with established thyrotoxicosis and 110 control patients who were euthyroid (figure). The mean erythrocyte zinc

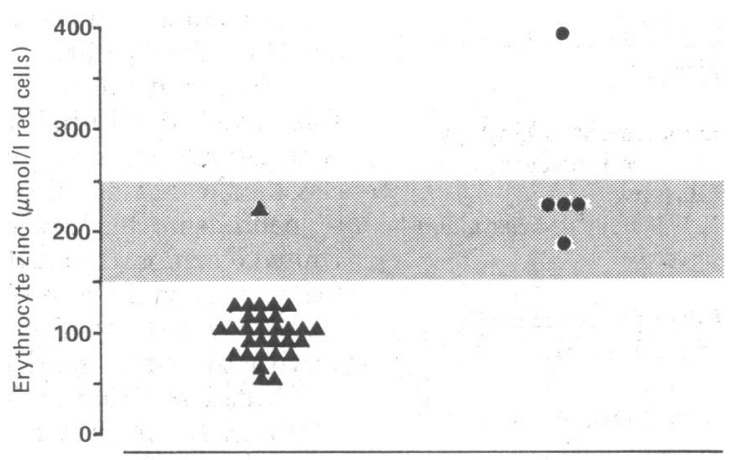

Hyperthyroidism

Subacute thyroiditis

Erythrocyte zinc concentrations in 30 patients with established thyrotoxicosis $(\boldsymbol{\Delta})$ and five patients with subacute thyroiditis $(\bullet)$. Hatched area shows 2 SDs of mean in 110 euthyroid control patients

concentration in the patients with thyrotoxicosis (105 (SD 64) $\mu \mathrm{mol} / \mathrm{l}$ red cells) was significantly lower than that in the euthyroid control patients (196 (50) $\mu \mathrm{mol} / 1$ red cells, $p<0 \cdot 001)$. The mean erythrocyte zinc concentration in the patients with subacute thyroiditis was, however, $255 \mu \mathrm{mol} / \mathrm{l}$ red cells (range $185 \cdot 6-394 \cdot 7)$ and not significantly different from that in the control group. One patient had an erythrocyte zinc concentration of $394.7 \mu \mathrm{mol} / 1$ red cells but he also had a thalassaemia trait with microcytosis.

\section{Comment}

The normal erythrocyte zinc concentrations in our patients show that their hyperthyroidism was transient and therefore provides additional evidence to support 
the diagnosis of subacute thyroiditis. These findings and those in our previous report of normal erythrocyte zinc concentrations in pregnant women with hyperemesis gravidarum ${ }^{2}$ show that the measurement of erythrocyte zinc concentration may be useful in distinguishing transient hyperthyroid states from established hyperthyroidism and might therefore be a valuable addition to the current range of thyroid function tests. Measurement of erythrocyte zinc concentration is fairly simple and provides information that cannot be obtained by conventional thyroid function tests. It may alert the clinician to the correct diagnosis, particularly in patients with "silent" thyroiditis with associated thyrotoxicosis, and therefore avoid inappropriate treatment.

I Swaminathan R, Segall NH, Chapman C, Morgan DB. Red blood cell omposition in thyroid disease. Lancet 1976;ii: 1382-5.

Lao TTH, Chin RKH, Swaminathan R, Panesar NS, Cockram CS. Erythrocyte anc in differential diagnosis of hyperthyroidism in pregnancy: a preliminary report. Br Med 7 1987:294:1064-5.

(Accepted 21 September 1989)

\section{Renal replacement treatment in patients with spina bifida or spinal cord injury}

\author{
G S Muralikrishna, R S C Rodger, \\ A I Macdougall, J M Boulton-Jones, \\ M E M Allison, K F Kyle, B J R Junor, \\ J D Briggs
}

\section{Renal Unit, Stobhill General Hospital, Glasgow G21 3UW}

G S Muralikrishna, MRCP, registrar in medicine R S C Rodger, MRCP, consultant physician

A I Macdougall, FRCP consultant physician

Renal Unit, Royal Infirmary, Glasgow J M Boulton-Jones, FRCP, consultant physician M E M Allison, FRCP, senior lecturer in medicine

\section{Renal Unit, Western} Infirmary, Glasgow B J R Junor, FRCP, consultant physician

J D Briggs, FRCP, consultant physician

Department of Urology, Western Infirmary, Glasgow

K F Kyle, FRCs, consultant surgeon

Correspondence to: $\mathrm{Dr}$ Muralikrishna.

Br Med f 1989;299:1506

Number of new patients with chronic pyelonephritis secondary to neurogenic bladder who started dialysis in west of Scotland and United Kingdom per million population, 1982-8

\begin{tabular}{lll}
\hline & $\begin{array}{c}\text { West of } \\
\text { Scotland }\end{array}$ & $\begin{array}{c}\text { United } \\
\text { Kingdom }\end{array}$ \\
\hline 1982 & $0 \cdot 36$ & $0 \cdot 22$ \\
1983 & $0 \cdot 73$ & $0 \cdot 31$ \\
1984 & $0 \cdot 36$ & $0 \cdot 38$ \\
1985 & 0 & $0 \cdot 33$ \\
1986 & 1.09 & $0 \cdot 18$ \\
1987 & $2 \cdot 18$ & $0 \cdot 16$ \\
1988 & 0.73 & $\star$ \\
\hline
\end{tabular}

^Data not available.
Before 1980 few patients with spina bifida or traumatic paraplegia started dialysis in British renal units, probably because doctors had an unsubstantiated belief that their prognosis was poor ${ }^{1}$ and because of a lack of resources to fund renal replacement treatment. ${ }^{2}$ Since then, however, successful treatment of the elderly and diabetics with renal failure, two other groups of patients expected to have a poor prognosis, has been described. ${ }^{34}$ We report our experience of treating patients with renal failure due to spina bifida or spinal cord injury.

\section{Patients, methods, and results}

Fifteen of 883 adults starting dialysis in the west of Scotland from January 1982 to December 1988 had renal failure due to spina bifida or spinal cord injury. Data from the European Dialysis and Transplant Association's registry show the number of patients classified as having chronic pyelonephritis secondary to neurogenic bladder who started dialysis in the United Kingdom during this period (table). We studied the patients until the end of February 1989, a follow up of four to 78 months, and calculated cumulative survival by using actuarial analysis.

The patients ( 10 men, five women) were of mean age 27 (range 16-50) years at the time of first referral to a nephrologist. Twelve had spina bifida, two traumatic paraplegia, and one traumatic tetraplegia. Fourteen had been referred because of renal failure ( 12 with a serum creatinine concentration $>500 \mu \mathrm{mol} / \mathrm{l}$ ), and eight of these patients started dialysis within six months. In all cases renal failure was attributed to neurogenic bladder and recurrent urinary tract infections, but severe hypertension (seven patients), amyloidosis (two), shunt nephritis (one), and renal calculi (one) were identified as additional contributory factors.

Eleven patients were treated by haemodialysis ( $\mathrm{six}$ at home) for a mean of 20 (range 2-53) months and four patients by continuous ambulatory peritoneal dialysis for 27 (3 to 55) months. Thirteen patients were considered suitable for transplantation after further urological assessment. Three of these patients received transplants 31-58 months after starting dialysis; all grafts were functioning at follow up eight to 35 months after transplantation, serum creatinine concentrations being 61-124 $\mu \mathrm{mol} / \mathrm{l}$. Three patients died 12-35 months after starting dialysis; all had been treated by haemodialysis in hospital, and all deaths were related to infection. Cumulative survival rates were $93 \%$, 93\%, and $62 \%$ at one, two, and three years respectively.

\section{Comment}

This study shows that the outlook for patients with renal failure due to spina bifida or spinal cord injury is good in the short and medium term. Survival is better than that for diabetics with end stage renal disease in the region. Moreover, many of the patients can be treated by dialysis at home, and most are suitable candidates for renal transplantation. Previous reports of treating such patients are scarce, but our experience compares favourably with that in California, where survival rates at one and two years were $60 \%$ and $52 \%$ respectively.

The data from the registry of the European Dialysis and Transplant Association suggest that a higher proportion of patients with spina bifida or spinal cord injury receive renal replacement treatment in the west of Scotland than in the rest of the United Kingdom. This suggests that non-nephrologists in our region are more aware than those in the rest of the United Kingdom of the value of treating renal failure in patients with paraplegia. Regrettably, these patients were often referred in advanced renal failure, and this has been observed in other groups of patients expected to have a poor prognosis. Our results indicate that all patients with neurogenic bladder should be referred to a nephrologist as soon as their blood pressure or serum creatinine concentration is raised, as we have not found any such patient to be unsuitable for renal replacement treatment.

We thank Professor F P Brunner, chairman of the European Dialysis and Transplant Association's registration committee, for permission to use previously unpublished data; Ms Sheila Dykes for making these data available; Mr A Azmy, of the Royal Hospital for Sick Children, Glasgow, for his useful advice; and Ms Shona Smillie for secretarial help.

Whitfield HN, Hendry WF, eds. Textbook of genitourinary surgery. Edinburgh: Churchill Livingstone, 1985:782.

Wing AJ. Why don't the British treat more patients with kidney failure? Br.Med f 1983;287:1157-8.

Taube DH, Winder EA, Ogg CS, et al. Successful treatment of middle aged and elderly patients with endstage renal disease. Br Med f 1983;286:2018-20.

Cameron JS, Challah $\mathrm{S}$. Treatment of end stage renal failure due to diabetes in the United Kingdom, 1975-84. Lancet 1986;ii:962-6.

5 Mirahmadi MK, Vaziri ND, Ghobadi M, Nikakh B, Gordon S. Survival on maintenance dialysis in patients with chronic renal failure associated with paraplegia and quadriplegia. Paraplegia 1982;20:43-7.

(Accepted 27 September 1989) 